\title{
HASIL PENGOLAHAN MOBIL PENGOLAH AIR BERSH DALAM PENYEDIAAN AIR BERSIH DAN AIR MINUM UNTUK LAYANAN BENCANA
}

\author{
Mariya Ulfa, Margono, Bambang Sunarko
}

\begin{abstract}
Water can be regarded as one of the sources of life. The absence of water may threaten the very survival of the ecosystems and all living creatures. In addition to daily consumption, water is also used for bathing and washing. Normally, water can easily be obtained provided there is no special event such as a natural disaster, where victims of such emergency will suffer from lack of potable or drinking water, despite the amount of aids provided by the government. Among other things, the government have introduced a mobile water treatment unit. This study was aimed at understanding the efficiency of such a mobile unit in providing water in disaster areas.

This was a descriptive study to present results of field observations and other data gathering methods in tables and other forms for comparison with relevant and appropriate standards. In addition to field observations data collection was carried out through interviews and measurements. The object under study was a mobile treatment unit owned and operated by the Badan Penanggulangan Bencana Daerah (BPBD).

Results of the investigation indicated that the mobile unit was being operated in efficient and effective manners in satisfying the need and demand for potable and drinking water. The treatment system in the mobile unit relied on Reversed Osmoses (RO) processes. The amount of water generated by this unit was $1000 \mathrm{~L} /$ hour for potable water and $600 \mathrm{~L} /$ hour for drinking water. Results of the microbiological, physical and chemical examinations have satisfied the designated requirements and standards.

The study suggested that all relevant staff should be able to operate the unit, as well as initiating manageable repairs when such things are called for. Minor problems pertaining to the unit can be solved on site and this may lessen the dependence on ouside assistance. The unit works quite well, therefore efforts should be directed at managing supplies, maintenance, and to provide pretreatment unit to improve unit's capability to treat raw water having turbidity of more than 30 NTU.
\end{abstract}

Keywords: disaster, emergency, mobile water treament unit

\section{PENDAHULUAN}

Air merupakan sumber kehidupan bagi makhluk hidup di bumi. Kekurangan air bisa mengancam kelangsungan hidup dan ekosistem. Bagi manusia, selain untuk konsumsi sehari-hari, air juga digunakan untuk mandi dan mencuci. Air juga menunjang upaya pembangunan infrastruktur seperti rumah, masjid, perkantoran, dan lainnya. Air juga merupakan bagian dari lingkungan fisik yang sangat esensiil bagi proses kehidupan.

Kebutuhan air bersih dan air minum di kota-kota besar di Indonesia telah dipenuhi dengan berbagai cara, misalnya melalui banyaknya depot air minum isi ulang yang siap dikonsumsi dengan harga relatif murah. Di pedesaan, air juga lebih mudah di peroleh, dan disamping itu air PDAM pun sudah mulai merambah wilayah pedesaan. Memperoleh air bersih akan sangat manakala tidak terjadi peristiwa memberatkan misalnya bencana alam. Bencana adalah serangkaian peristiwa yang menimbulkan gangguan serius pada kehidupan masyarakat, menyebabkan korban jiwa serta kerugian yang meluas baik dari segi materi, ekonomi, maupun lingkungan, dan seringkali melampaui kemampuan masyarakat untuk mengatasinya dengan mengandalkan sumberdaya yang mereka miliki. Rangkaian peristiwa yang mengancam dan mengganggu kehidupan dan penghidupan masyarakat bisa disebabkan oleh faktor alam dan atau faktor non alam, maupun faktor manusia sendiri, bisa mengakibatkan timbulnya korban jiwa manusia, kerusakan 
lingkungan, kerugian harta benda, dan dampak psikologis. (UU No. 24 tahun 2007). Karena aspek geologis, iklim, dan letaknya yaitu pada pertemuan tiga lempeng tektonik dunia, Indonesia memiliki lebih dari 128 gunung berapi aktif, sekitar 150 sungai, baik besar maupun kecil, yang melintasi wilayah padat penduduk.

Korban yang masih hidup sangat di lokasi bencana mengalami kesulitan untuk memperoleh sediaan air bersih dan air minum. Sementara disadari bahwa air bersih berpengaruh terhadap kehidupan. Banyak cara telah dilakukan pemerintah untuk menangani permasalahan pasca bencana khususnya untuk memulihkan kelangsungan hidup manusia yang sangat memprihatinkan, utamanya berupa bantuan logistik baik melalui jalur udara, laut, maupun darat.

Salah satu upaya Pemerintah ialah menciptakan suatu unit dengan rancangan khusus untuk pemenuhan kebutuhan air bersih dan air minum di lokasi bencana yaitu berupa mobil pengolah air bersih. Mobil tersebut mempunyai dua fungsi yaitu untuk pemenuhan air bersih dan pemenuhan air minum. Mobil yang dimiliki oleh Badan Penanggulangan Bencana Daerah (BPBD) sudah beroperasi selama dua tahun, namun sampai sekarang belum pernah dilakukan pemeriksaan kualitas air produksinya. Kali terakhir mobil tersebut digunakan di kabupaten Gresik untuk penyediaan air bersih terkait terjadinya bencana banjir, yang disebabkan oleh meluapnya Sungai Bengawan Solo dan jebolnya tanggul Sungai Lamong (24/03/2013). Mobil pengolah datang untuk memasok air bersih dengan air baku yang diambil dari air Sungai Lamong yang berada di daerah Gresik.

Penelitian ini ditujukan untuk melakukan pemeriksaan kualitas air yang dihasilkan oleh mobil tersebut guna mengetahui kinerja mobil pengolahan air bersih dalam upaya penyediaan air bersih dan air minum.

\section{METODE PENELITIAN}

Data primer dari penelitian ini yaitu data yang didapatkan atau yang diukur sendiri pada saat penelitian, melalui observasi atau pengamatan/peninjauan langsung ke BPBD, wawancara dengan penanggung jawab atau operator mobil pengolah. Sementara data hasil pengukuran kualitas air secara bakteriologis yaitu E.Coli, hasil pengukuran kualitas air secara fisik yaitu TDS, kekeruhan, warna, bau, rasa dan suhu, hasil pengukuran kualitas air secara kimia yaitu bilangan $\mathrm{KMnO}_{4}$ dan $\mathrm{pH}$. Sedangkan data sekunder diperoleh dari Kantor Badan Penanggulangan Bencana Daerah (BPBD) Waru-Sidoarjo, selebihnya dikumpulkan dari literatur, buku-buku, laporan maupun skripsi yang terkait.

Teknik pengumpulan data yang digunakan antara lain adalah wawancara yang dilakukan terhadap pihak penanggung jawab mobil pengolahan air bersih, yaitu mengenai kegiatan pengoperasian mobil pengolahan air bersih dengan menggunakan pedoman atau panduan wawancara. Selain itu ialah pengukuran suhu, $\mathrm{pH}$, warna, bau dan rasa pada air hasil pengolahan. Pemeriksaan laboratorium dilakukan untuk parameter TDS, kekeruhan, kandungan E. coli, dan zat organik.

\section{HASIL PENELITIAN DAN PEMBAHASAN}

Mobil pengolah air bersih merupakan suatu alat untuk menyediakan pasokan air bersih dan air minum. Mobil pengolah ini dapat dipindah-pindahkan ke berbagai tempat karena terdiri dari kendaraan mini truk, unit pengolah dan generator set (Genset). Mobil ini terbagi menjadi 3 bagian. Bagian depan adalah wilayah pengemudi, dapat diisi oleh 3 orang. Bagian tengah berisi unit pengolahan, yang berbentuk tabungtabung. Unit pengolahan itu terdiri dari desinfektan berupa kaporit, saringan yang menggunakan pasir silika, adsorben arang aktif, bahan softener untuk menghilangkan kesadahan, sistem RO, dan lainpu UV. Bagian belakang berisi tangki pengolahan untuk membuat air bersih. Tangki ini berbentuk bulat dengan sekat-sekat . Pada bagian ini terdapat 4 langkah pengendapan, dan tangki yang ke 5 menampung air hasil olahan, sedangkan genset berada pada bagian belakang mobil ini.

Mobil pengolahan air bersih mempunyai ukuran yang relatif besar dengan panjang $5 \mathrm{~m}$ dan lebar $2 \mathrm{~m}$. Kapasitas produksi mobil ini mampu menghasilkan air bersih sebanyak $1000 \mathrm{l} / \mathrm{jam}$ dan menghasilkan air minum sebanyak $600 \mathrm{l} /$ jam. 
Efisiensi unit mobil pengolah air bersih

Alat yang dimiliki oleh Badan Penanggulangan Bencana Daerah (BPBD) dikatakan efisien, berdasarkan data yang pemeriksaan sampel air setelah melalui proses penjernihan untuk penyediaan air bersih maupun air minum telah memenuhi syarat kesehatan. Komponen yang dimiliki mobil tersebut dapat membunuh kuman, bakteri, dapat menetralisir bahan kimia dan bahan fisik yang ada dalam air.
Pengoperasian alat sangat mudah karena yang perlu dilakukan hanyalah membuka dan menutup kran-kran penghubung dari satu komponen ke komponen lain ataupun menekan tombol panel terkait proses-proses.

Proses pengolahan air bersih dan air minum Proses pengolahan air bersih dan air minum di dalam unit pengolah secara keseluruhan adalah sebagai berikut:

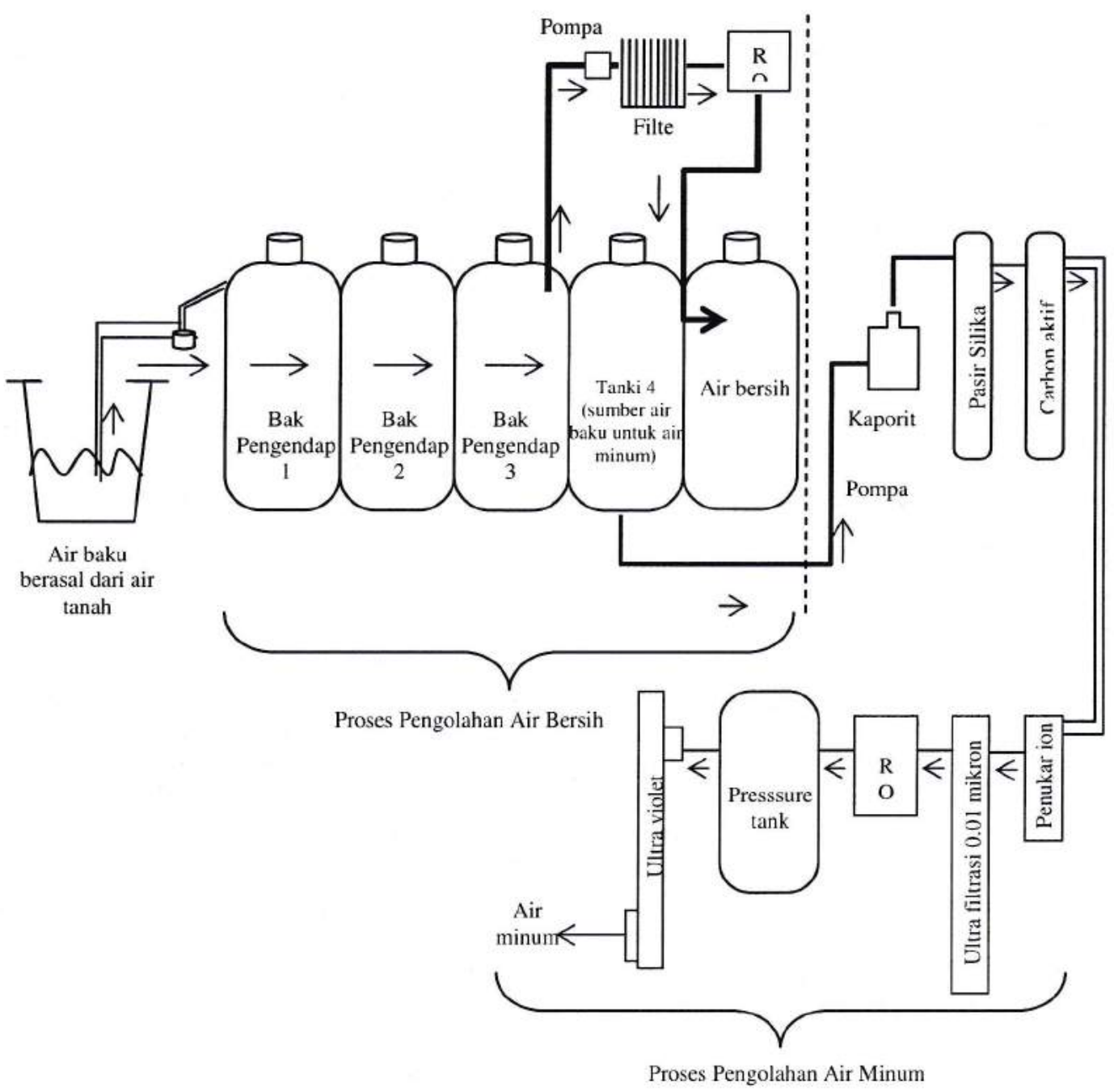


Terdapat beberapa tahap proses pengolahan untuk mendapatkan air bersih. Di dalam tangki mobil tersebut terdapat 4 bak pengendapan, setelah melalui pengendapan 1, pengendapan 2, dan pengendapan 3, air masuk ke dalam filter, kemudian dilanjutkan ke sistem RO sehingga mendapatkan air bersih. Mobil pengolah ini juga dapat menghasilkan air minum. Air baku untuk membuat air minum didapatkan dari air bersih yang berada pada tangki pengendapan 4. Proses yang terjadi untuk mendapatkan air minum antara lain adalah air baku yang mengalir menuju filter/saringan pasir, lalu mengalami desinfeksi menggunakan kaporit, berlanjut ke penukar ion, Ultrafiltrasi, RO, adsorbsi dengan arang aktif, dan diakhiri dengan penyinaran oleh Lampu UV untuk menghasilkan air minum.

\section{Kualitas air minum yang dihasilkan dari unit mobil pengolahan air bersih. Kualitas bakteriologis}

Berdasarkan hasil uji bakteriologis dengan parameter E-coli dapat diketahui bahwa air minum hasil olahan dari unit mobil hasilnya adalah negatif. $\mathrm{Hal}$ ini sesuai dengan Peraturan Menteri Kesehatan RI No. 492 Tahun 2010 yang didalamnya menetapkan kadar maksimum yang diperbolehkan untuk parameter jumlah $\mathrm{E}$. Coli per $100 \mathrm{ml}$ sampel adalah nol. Ini dikarenakan salah satu proses pengolahan untuk menghasilkan air minum adalah desinfeksi. Desinfeksi adalah proses yang dilakukan untuk membunuh bakteri pathogen dengan membubuhkan bahan kimia yaitu kaporit. Pembubuhan ini merupakan sterilisasi tahap awal dan juga berfungsi sebagai oksidator. Kaporit berada di dalam tabuing dan selama pengoperasian harus selalu dalam kondisi terisi. Proses diakhiri dengan penyinaran ultraviolet yang memungkinkan bakteri dan virus mati. Penyinaran dengan ultraviolet merupakan cara disinfeksi yang efektif, kecuali terhadap spora jamur, virus yang tahan terhadap sinar UV atau memerlukan waktu penyinaran yang lebih lama.

Kualitas fisik

Hasil penelitian menunjukkan kadar TDS sebesar $60 \mathrm{mg} / \mathrm{l}$, kadar kekeruhan sebesar 0,87 NTU, tidak berwarna, tidak berbau, tidak berasa, dan suhu air sekitar $30^{\circ} \mathrm{C}$. Hal ini sesuai dengan Peraturan Menteri Kesehatan RI No. 492 Tahun 2010 tentang kualitas fisik air minum, dimana parameter kadar maksimum yang diperbolehkan untuk TDS adalah $500 \mathrm{mg} / \mathrm{I}$, kadar maksimum yang diperbolehkan untuk kekeruhan adalah 5 NTU, tidak berbau, tidak berasa, dan tidak berwarna. Hasil olahan air minum memenuhi syarat kesehatan berdasarkan Peraturan Menteri Kesehatan tersebut di atas. Di dalam unit terdapat sistem RO yang mampu menurunkan kadar TDS. RO menggunakan membran yang dapat menyaring partikel sangat kecil seperti padatan terlarut. Air melewati membran semi-permeabel (dalam modul RO) dan hanya molekul air bersih saja yang mampu melewati pori-pori membran, sedangkan molekul yang berdiameter lebih besar tidak mampu menembus dan terbuang keluar, yang lazimnya di sebut sebagai air "reject". Agar reversed osmosis berjalan baik perlu dipastikan agar membran tidak tersumbat oleh kotoran. Di dalam unit terdapat saringan pasir silika yang berfungsi menyaring kotoran dengan besaran di atas 50 mikron, dan mengurangi tingkat kekeruhan air, tujuan utama penyaringan adalah untuk mendapatkan air yang jernih. dan terdapat karbon aktif yang berfungsi menyerap warna, bau, dan rasa. Adsorbsi merupakan akumulasi ion dan molekul pada suatu permukaan. Bahan karbon aktif memiliki permukaan yang sangat luas yang terbentuk oleh oksidasi terhadap karbon.

\section{Kualitas kimia}

Dari hasil penelitian diketahui bahwa di dapatkan hasil pemeriksaan $\mathrm{KMnO}_{4}$ sebesar $3,29 \mathrm{mg} / \mathrm{l}$ dan pemeriksaan $\mathrm{pH}$ adalah 7 . Hal ini sesuai dengan Peraturan Menteri tersebut di atas yang mencakup kualitas kimia, salah satunya adalah derajat $\mathrm{pH}$ harus berada antara 6,5-8,5. Derajat keasaman $(\mathrm{pH})$ air ini penting untuk menentukan daya guna perairan baik untuk keperluan rumah tangga, irigasi, kehidupan organisme perairan dan kepentingan lainnya. Sedangkan untuk parameter zat organik $\left(\mathrm{KMnO}_{4}\right)$, kadar maksimum yang diperbolehkan yaitu $10 \mathrm{mg} / \mathrm{l}$. Bahan-bahan organik dalam air erat hubungannya dengan terjadinya perubahan sifat fisik dari air, terutama dengan timbulnya warna, bau, rasa dan kekeruhan yang tidak diinginkan. Kandungan zat organik dalam air dapat diketahui dengan menentukan bilangan permangat. Adanya proses pengolahan adsorbsi arang aktif dapat menurunkan zat organik dalam air sehingga 
tidak menimbulkan masalah bau, rasa dan warna.

\section{Kualitas air bersih yang dihasilkan} dari unit mobil pengolahan air bersih.

Berdasarkan hasil penelitian dapat diketahui bahwa hasil olahan menunjukkan kadar TDS sebesar $220 \mathrm{mg} / \mathrm{l}$, kekeruhan air besarnya 1,24 NTU, tidak berwarna, tidak berbau, tidak berasa, sedangkan suhunya $30^{\circ} \mathrm{C}$, dan $\mathrm{pH} 8$. Hal ini sesuai dengan Peraturan Menteri Kesehatan RI No. 416 Tahun 1990. tentang kualitas fisik air bersih, dimana kadar maksimum yang diperbolehkan untuk parameter TDS sebesar $1.500 \mathrm{mg} / \mathrm{l}$, kadar maksimum yang diperbolehkan untuk kekeruhan adalah 25 NTU, dan tidak berbau, tidak berasa. Proses pengolahan untuk menghasilkan air bersih yang memenuhi syarat kesehatan berdasarkan peraturan perundangan yang berlaku sangat terbantu dengan adanya sistim RO yang dapat menurunkan kadar TDS. RO ini menggunakan membran yang dapat menyaring partikel sangat kecil seperti dissolved solid, dan inipun didahului oleh proses pengendapan pada bak pengendap 1 sampai 3 .

Hasil wawancara

Wawancara antara lain dilakukan untuk mengetahui kondisi pemakaian APD saat pengoperasian alat dan pendistribusian ke korban bencana. Adapun APD yang dimaksud yaitu : Sarung tangan, Masker, Topi, pakaian lengkap dan sepatu. Fungsi APD dalam pendistribusian air yaitu, meminimalisir terjadinya kontaminasi pada air terhadap pekerja yang mendistribusikan air bersih maupun air minum.

\section{KESIMPULAN}

1. Sistem dalam mobil pengolahan ini antara lain menggunakan system Reversed Osmosis, desinfektan, penyaringan pasir silika, karbon aktif, penukar ion dan UV.

2. Menghasilkan air bersih $1000 \mathrm{l} / \mathrm{jam}$ dan untuk air minum $600 \mathrm{l} / \mathrm{jam}$.

3. Pemeriksaan bakteriologi air minum hasil olahan memenuhi syarat.

4. Pemeriksaan fisik air minum hasil olahan memenuhi syarat.

5. Pemeriksaan kimia air minum hasil olahan memenuhi syarat.

6. Berdasarkan standar yang berlaku yaitu untuk air bersih (Peraturan menteri Kesehatan RI No. 416 Tahun 1990) dan untuk air minum (Peraturan Menteri
Kesehatan RI No. 492 Tahun 2010) air bersih dan air minum hasil olahan memenuhi syarat kesehatan.

\section{SARAN}

1. Semua petugas sebaiknya tidak hanya dapat mengoperasikan, tetapi juga harus mampu menangani alat manakala terjadi kerusakan.

2. Agar lebih memperhatikan persediaan bahan dan suku cadang.

3. Agar lebih memperhatikan kebersihan alat

4. Sebaiknya dilengkapi dengan tahap pengolahan awal untuk mengatasi air dengan kadar kekeruhan di atas 30 NTU.

\section{DAFTAR PUSTAKA}

Hartomo, A.J. dan Widiatmoko, M.C, 1994. Teknologi Membran Pemurnian Air. Yogyakarta:Andi Offset

Kumalasar, F dan Satoto, Y, 2011. Teknik Praktis Mengolah Air Kotor menjadi Air Bersih.Bekasi-Jawa Barat: Laskar Aksara

Margono, 2008. Penyediaan Air Bersih. Surabaya (Tidak Dipublikasikan)

Menkes RI, 2010. Peraturan Menteri Kesehatan No.

492/MENKES/PER/IV/2010 Tentang Persyaratan Kualitas Air Minum. Jakarta

Menkes RI, 1990. Peraturan Menteri Kesehatan No. 416/MENKES/PER/IX/1990 Tentang Syarat-syarat Dan Pengawasan Kualitas Air. Jakarta

Notoatmodjo,S, 2010. Metodologi Penelitian Kesehatan. Jakarta: Rineka Cipta

Notoatmodjo, Soekidjo, 2010. Metodologi Penelitian Kesehatan. Jakarta: PT Rineka Cipta

Poltekkes Kemenkes Surabaya, 2011. Pedoman Penulisan Karya Tulis Ilmiah. Surabaya:Jurusan Kesehatan Lingkungan

Purwanto, D.S, 2011. Teknik Pengolahan Air Minum. Surabaya (Tidak Dipublikasikan)

Sugiharto, 1983. Penyediaan Air Bersih Bagi Masyarakat. Tanjungkarang

Sutrisno, C.Totok, dkk, 2006. Teknologi Penyediaan Air Bersih. Jakarta: PT Rineka Cipta. 